\title{
From Confiscated Properties to New Possibili- ties for Redevelopment: The State of Returned Properties of the Catholic Church in Zagreb
}

\author{
Josip KAJINIĆ and Martina JAKOVČIĆ, both Zagreb*
}

with 4 figures and 2 tables in the text

\section{Content}

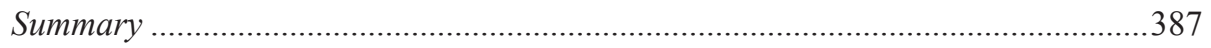

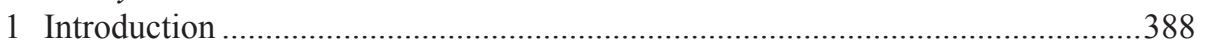

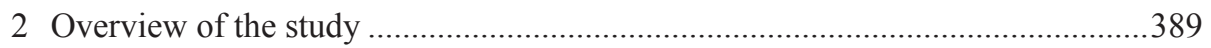

3 Process of deprivatisation and confiscation of assets after 1945...........................390

4 Return of property to the Catholic Church in the area of the City of Zagreb .......393

5 State of returned properties and transformations executed ...................................396

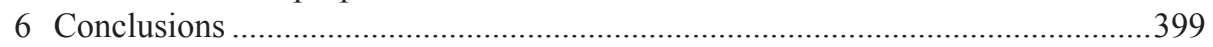

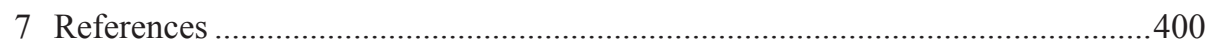

\section{Summary}

The rise of the Communist system in Yugoslavia in 1945 was accompanied by a severe nationalisation process for properties held by private persons and religious communities, especially the property of the Catholic Church. Confiscation was regulated by different laws, i.e. Act on Agrarian Reform and Colonisation (1945), Nationalisation Act (1946 and 1948) and Expropriation Act (1947). With the fall of the Communist system in the 1990s and pursuant to the 1992 agreement between the Republic of Croatia and the Holy See and especially the 1998 agreement on economic affairs, the processes of returning confiscated properties and/or reimbursement

* Josip KAJINIć, PhD., Croatian Institute of History, Opatička 10, HR-10000 Zagreb, Croatia; email: jkajinic@isp.hr; Martina JAKovČIĆ, PhD., Assistant professor, University of Zagreb, Faculty of Science, Department of Geography, Marulićev trg 19, HR-10000 Zagreb, Croatia; email: mjakovci@geog.pmf.hr 
for those properties began. Pursuant to these agreements, the issue of returning confiscated properties was approached bilaterally between representatives of the government commission for relations with religious communities and the bishop's commission of the Croatian bishops' conference. This paper analyses the state of return or transformation of confiscated properties owned by the Catholic Church and the possibilities for their redevelopment. Although the majority of the buildings have been returned to the Catholic Church "by law", in reality they continue to be occupied by the previous inhabitants.

\section{Introduction}

With the establishment of Communist rule in Yugoslavia following World War II, the process of nationalisation and confiscation of property held by private entities and religious communities began. One of the communities most affected by the property confiscation process within the territory of the Socialist Republic of Croatia was the Catholic Church. The process of returning seized properties began after 1990 and the breakdown of the Socialist Federative Republic of Yugoslavia, parallel to the process of political and economic transition.

This paper gives an overview of the state of the return and transformation of properties confiscated from the Catholic Church in the area of the City of Zagreb. The first part of the paper gives an outline of the process of confiscating the property of religious communities after 1945, for the purpose of a clearer understanding of the events after 1990. Also, the primary laws enabling such proceedings are outlined. The second part of the article describes the situation after 1990. Though there were some individual requests for property returns prior to 1990, the broader process of return began only after the fall of the Communist system, on the basis of four agreements concluded between the Republic of Croatia and the Holy See. The second part of the paper gives a brief explanation of the agreements pursuant to which properties could be returned to the Catholic Church. The third, central part of the paper, analyses the dynamics of return of confiscated properties, the state of the returned structures, and planned and implemented transformation. This structure of the paper is in line with the set objectives. The first objective of the paper is to outline the current state of the return of property to the Catholic Church in the City of Zagreb and to determine the type of property return, in line with the KozMINSKI model. The second objective is to evaluate the state of the properties, and the degree of implemented transformation.

The spatial boundary of the study is the City of Zagreb. As such, it is necessary to emphasise that only the return of confiscated buildings and lands was analysed. Due to the complexity and spatial scope, the return of agricultural lands was not examined, which represents a potential area for further study. 


\section{Overview of the study}

To date, the confiscation of the assets of the Catholic Church after 1945 has been the subject of relatively few domestic and foreign scientific studies. The majority of the available literature deals with the general position of the Catholic Church in the period of Communist rule, in which expropriation is only listed as one of the acts implemented for the purpose of reducing the influence of religious communities. Among the relatively many papers on that topic, the papers of AKMADŽA on the position of the Catholic Church in Croatia and its relations with the Communist regime are most prominent $(2004,2005,2013)$. Other papers dealing with the relationship between the Catholic Church and Communist authorities in Croatia and Yugoslavia are those by Alexander (1979) and Buchenau (2006). AkmadžA (2003) dealt with the topic of the seizure of church properties and gave an overview of the seized properties held by the Zagreb Archdiocese, with an emphasis on lands and agricultural assets. KozMINSKI (1997) listed several types of nationalisation implemented in the countries of Central and Eastern Europe after 1945. One type listed was the expropriation of properties owned by the religious communities. That paper also listed the issue of the lack of documentation of such acts, which would later result in numerous problems arising during the process of returning assets after 1990 (KOZMINSKI 1997).

In order to provide an overview of the broader context of the processes of nationalisation and denationalisation, papers dealing with the position of the Catholic Church in Poland and the former Czechoslovakia were also consulted, among them Kumka (2003), Chalupecky (2003a, 2003b) and Olexak (2003). An overview of the activity of the Catholic Church in Slovenia in the 1960s was provided by GRIESSER PEČAR (2003), and after the 1960s by Dolinar (2003). A brief overview of the activity of the Catholic Church in Hungary from 1945 to 2005 was given by BeKE (2003). A significant barrier in the study is the lack of comparative studies. One of the rare papers dealing with the issues of property confiscation and which compares the processes in Croatia and Bosnia and Herzegovina is that by GolužA \& LuČIĆ (2006).

There are even fewer papers dealing with the return of properties confiscated after 1945, and particularly with the state of the returned structures. If there are papers, they primarily deal with the church-state relations, and only mention the return of property as an outstanding issue. For example, KoRBONSKI (2000) gave an overview of church-state relations in Poland a decade after the fall of Communism, and analysed the outstanding issues, such as religious education, birth control, Christian values, freedom of the press, church finances, issues of anti-Semitism, and inclusion of the Church as a political player. One of the rare papers examining the return of property in the countries of Central and Eastern Europe was Kozminski (1997). In this paper, he listed four types of reprivatisation or property return: return of confiscated property to the original owner, return of property of equal value, monetary compensation, and reprivatisation vouchers. Furthermore, KozMINSKI analysed the state and procedures 
of property return in certain post-Socialist countries, with examples from the former Democratic Republic of Germany, Slovakia, Czechia, Hungary, Bulgaria and Poland. The differences in the procedures of returning property were described in detail in the chapter "Return of property". The geographic implications of the return of property were addressed by BORN (1997), who examined the implications in the former East Germany. The study by ReImAnN (1997) is also interesting, as it examined the consequences of the return of property on urban development and reconstruction in the area of the former East Berlin.

There are a number of papers on the changes to zoning and changes to the spatialfunctional structure of urban areas in general, and in particular of post-Socialist towns. Most of these papers deal with the rezoning of abandoned industrial and military brownfield sites. Among the studies dealing with changes to the spatial-functional structure of post-Socialist towns is Kiss (2009), which addressed changes to a former industrial area in the vicinity of Budapest. KотUs (2006) addressed the changes in the spatial structures of Polish cities such as Poznań, while SyкоRA (1999) looked at the processes of socio-spatial differentiation in post-Communist Prague [Praha]. CizLer (2012) gave an overview of the effects of urban regeneration on the heritage and local community. PoLAnska (2008) explained the functional and spatial changes of post-Socialist cities, emphasising the political and cultural aspects of change. The literature addressing the rezoning and changes to the spatial and functional structures of Croatian cities includes studies by KNEŽEvić (1999, 2003, 2011a, 2011b), which looked at the transformation of the space of the Rudolph military bases. The neighbourhood Črnomerec and transformations within were addressed by JAKOVČÍć (2014). Current revitalisation projects and the transformation of spatial structures in the city were examined by SvirČIĆ GotovaC (2011), while ČALDAROVIĆ \& ŠArINIÍ (2008) explained the processes of transformation and gentrification in Croatian cities. Despite the growing trend in the literature examining the transformation of city spaces in general, and particularly in post-Socialist cities, there is a lack of literature regarding the return and transformation of sacral structures.

\section{Process of deprivatisation and confiscation of assets after 1945}

After 1945, all of the Communist states in Central and Eastern Europe began to implement the procedure of nationalisation, deprivatisation and confiscation of personal property, to a smaller or greater extent. There were, however, differences among states. For example, in Poland, almost $85 \%$ of the agricultural lands were under private ownership, and there was the possibility of private or cooperative ownership of houses and flats, and the ability to launch small, private companies with up to 50 employees. 
Similar situations were present in Hungary and the Democratic Republic of Germany. However, state control was high in all countries (KozMINSKI 1997). Expropriation after 1945 took place in several models in the countries of Central and Eastern Europe: with the nationalisation of larger companies, apartment blocks, shops and the like pursuant to special laws; 'spontaneous' nationalisation that was implemented by the local Communist party; confiscation of property of politically unfavourable individuals; expropriation of the property of church and religious communities, and the violent seizure of private ownership and assets (KozMINSKI 1997). Expropriation of the property of church and religious communities was often part of the anti-religious campaign of the regime.

Upon the completion of World War II in 1945, the Communist Party took over rule in the newly established state of Yugoslavia, and in its component republic, Croatia. From the start, the state authorities systematically followed and applied the Soviet administration model, in which the Communist authorities were in deeply rooted conflict with the Catholic Church, as clearly outlined by one of the founders of the concept of Communism, Karl Marx, who claimed that "religion is the opium of the masses". Furthermore, the Communist ideology, with its very inclination for revolutionary change, was contrary to anything lasting and permanent, such as religions or religious communities, and among them was the Catholic Church. For those reasons, the Church was a barrier to the Communist ideology, which saw its survival only in the case of the failure of the Church and all other religious communities. The situation culminated on 19 March 1937, when Pope Pius XI published the Divini Redemptoris, which sharply condemned the Communist social movement. The position of the Soviet Communists was shared by Communist sympathisers in Croatia. Religions and religious organisations were, in their eyes, part of a broken-down system, which aimed to disable the spread of their Communist ideals. The objective of the Communist party was to take over the role of the one and only ideological and political authority, and for that reason, no form of opposition to this goal was acceptable.

Immediately after the establishment of the new Communist rule, many forms of repression against the Catholic Church in Yugoslavia began. The most drastic result of this repression was certainly the killing of 243 priests, 19 theologians, 3 monks and 4 nuns to September 1945, as well as the imprisonment of 169 members of the clergy and the disappearance of another 89 (BATELJA 2010a; BATELJA 2010b; AKMADŽA 2004). By 1990, that figure climbed to 583 clergy members killed (RADELIĆ 2006; KožUL 1998). Other methods of repression of the regime against the Church were directed at prohibiting the teaching of catechism in schools, the abolishment of a large number of seminaries, religious schools and theology faculties, and disabling the printing and publishing activities of the Church (AKMADŽA 2003a). The Catholic press was prohibited, and all church printing presses seized. Of the 137 pre-war newspapers throughout the territory of Yugoslavia, by the end of July 1947, only four remained: two weeklies, one bi-weekly and one monthly (AKMADŽA 2004). 
The third form of retaliation of the Communist authorities against the Catholic Church, which is also key for the research topic of this paper, was directed towards materially impoverishing the Catholic Church, with the aim of disabling its activities. It aimed to achieve this goal by systematically confiscating church property. Due to the difficult economic situation, and in order to feed the numerous refugees, the state authorities decided to implement agrarian reforms and to colonise the population onto devastated lands through an act passed on 23 August 1945 at the federal level, and on 24 November 1945 for the territory of the federal state of Croatia (PERIĆ 2007; AKMADŽA 2003a). This law limited the personal possession of lands to only 30 ha, while the church and other religious institutions were limited to possession of only 10 ha (MAтіскA 2007). Furthermore, with this act, all church estates larger than 10 ha were confiscated, with very rare exceptions, and with no possibility of payment of any form of compensation. One year later, the Nationalisation Act was passed on 5 December 1946 and later amended on 28 April 1948 (Perić 2007). With this Act, the property of private enterprises, wealthy citizens and religious communities, predominantly that of the Catholic Church, was seized. With the amendments of 1948, entire sectors of industry, banking, trade, mining, insurance and most hospitality enterprises were also nationalised. The third and final amendment of this Act in December 1958 led ultimately to the seizure of rental buildings and construction lands (PERIĆ 2007). Among the many entities affected by these regulations, the greatest material effect was felt by the Catholic Church. With this Act, almost 23,000 acres or $82 \%$ of lands owned by the Zagreb Archdiocese were confiscated (AKMADŽA 2003b). In addition to this Act, the assets of the Catholic Church were also seized pursuant to the 1946 Act on the Nationalisation of Private Economic Entities and its 1948 amendments, and the 1947 Expropriation Act (AKMADŽA 2004).

With the application of these laws in the territory of the City of Zagreb, 67 of the total 131 properties of the Catholic Church were seized. Of those 67 properties, 48 were owned by the Zagreb Archdiocese, while 19 were owned by individual parishes and seminary communities in the City of Zagreb. Among these 19 were the buildings of the parish of St. John and St. Peter in the Upper Town, St. Blaise in the Lower Town, St. Emeric in Šestine, Our Lady of Help in Knežija, St. Anthony in the Sveti Duh neighbourhood, St. Anne in Rudeš, St. Joseph in Trešnjevka and the Blessed Virgin Mary in Stenjevec. Of the seminary communities, the most properties were seized from the male order of the Brethren of Jesus and the Franciscan order of the Lesser Brethren, and the female orders of the Servants of the Little Jesus and the Society of the Sisters of Mercy of St. Vincent of Paul. The buildings seized that had previously been in the ownership of the Zagreb Archdiocese had previously been used as seminaries for the education of priests, institutions for the retired clergy, and as residential quarters for the many church servants and staff.

The seized construction lands and buildings were, in most cases, transformed into educational institutions, scientific institutions, state offices and social institutions. On the confiscated lands, the national police school, industrial factory schools (A. 
Žaja, Sila and Građevinar) and the Institute of Engineering and Architecture were opened. Other residential complexes retained their residential purpose, but with new inhabitants. Also, it should be noted that the state authorities paid only negligible financial compensation to the Church for only a very small number of the seized buildings and lands (Table 1).

Table 1: Financial compensation for seized structures, paid in the period to 1990

\begin{tabular}{|r|l|l|r|}
\hline No. & \multicolumn{1}{|c|}{ Owner } & \multicolumn{1}{|c|}{ Address } & \multicolumn{1}{|c|}{$\begin{array}{c}\text { Compensation } \\
\text { paid (dinars) }\end{array}$} \\
\hline 1. & Parish of Our Lady of Help & Omiška 2 & 177,607 \\
\hline 2. & Parish Sesvete & Kašinska 1b & 752,250 \\
\hline 3. & Prebenda St. John & Ljubljanica & 73,810 \\
\hline 4. & Zagreb Archdiocese & $\begin{array}{l}\text { Complex Habdelićeva 1- } \\
\text { Kamenita 11 - Kamenita 13 - } \\
\text { Kamenita 15 }\end{array}$ & $3,593,000$ \\
\hline 5. & $\begin{array}{l}\text { Zagreb Archdiocese - } \\
\text { Pension office of the Zagreb } \\
\text { Archdiocese }\end{array}$ & $\begin{array}{l}\text { 3 buildings: Teslina 11, } \\
\text { Palmotićeva 3, Vinogradska 76 }\end{array}$ & 263,256 \\
\hline
\end{tabular}

Source: Archive of the archdiocese spiritual office of the Zagreb Archdiocese; Croatian State Archive - Committee for relations with religious communities

\section{Return of property to the Catholic Church in the area of the City of Zagreb}

The process of returning property, reprivatisation or the payment of compensation for seized and transformed property has been complex and long-lasting. A particularly significant problem is the scarce documentation on seizure procedures and the slow legislation in the former Communist states (KozMinski 1997). A large problem in the reprivatisation of property is the fact that these properties experienced significant physical and functional changes over time. Numerous structures were abandoned or inadequately maintained. On the other hand, individual structures were expanded, and significant state funds invested in them, and their function altered (KozMINSKI 1997). The result of these limitations is seen in the two means of the actual return of assets. The first was the return by law, where the assets were formally returned for use, but in practice there were no changes. The second was the return in practice, where the new user actually received the assets for use and determined the function of the assets. 
The processes of returning assets differed in individual post-Socialist states, with regard to the time period, the number and socio-economic structure of the former owners, and the type of structures claimed. In the former East Germany, the return of property was relatively quick, though former owners did not attain the right to return if the property after seizure had received a social, residential or state character, or if the company employed a large number of workers and if the privatisation hindered its functioning. As stressed by KozMINSKI (1997), during the reprivatisation process in the former East Germany, economic reasons prevailed over a 'historical right' or the right of ownership. In the area of the former Czechoslovakia, four acts were passed to regulate reprivatisation, in which one of the acts pertained to the return of properties that had previously belonged to churches and religious communities (KozMINSKI 1997). The reparation or return process was exceptionally slow and, in Poland for example, the first act on reprivatisation was adopted in the mid 1990s, while in Russia, the level of compensation was set to a maximum of 100 average monthly wages (KozMINSKI 1997).

With the change in the socio-political system and the fall of Communism in Yugoslavia in 1990, and the accompanying changes in its integral part Croatia, there were also changes with regard to the position of the Catholic Church. In the newly established circumstances, denationalisation procedures and procedures to return properties seized under Communism were launched. These procedures were initiated by common citizens, private enterprises, and by the Church. Considering the specific position of the Church and the fact of its universality and administration outside the borders of Croatia, and the fact that its seat, the Holy See, holds a position of national sovereignty in the international policy sense as the Vatican City State, the issue of returning church property took on an international and bilateral character. As such, this issue was finally resolved through one of four agreements signed between the representatives of the Holy See and the Republic of Croatia. The first three agreements were signed on 19 December 1996 in Zagreb, and dealt with legal matters, cooperation in the fields of education and culture, and on the spiritual care of the Catholic members of the armed forces and military services of the Republic of Croatia. The fourth and final agreement was the agreement on economic matters, which was signed on 9 October 1998. Article 2 of this final agreement defined the obligation to return to the Church all properties that had been seized by the former Communist regime. This Article states that the Republic of Croatia is obliged to:

(a) return to the Catholic Church the property confiscated during the period of the Yugoslav Communist rule, and which could be returned pursuant to the legal regulations;

(b) find appropriate substitutes for those assets that cannot be returned;

(c) pay compensation in monies to the legal persons of the Catholic Church for other assets that are not to be returned. 
The following points of the Agreement state that the properties are to be returned "in a reasonable time frame" and that for this purpose, a mixed committee be established consisting of representatives of the Government of the Republic of Croatia and the Croatian Bishop's Conference, and entrusted with compiling the list of assets to the returned, and to define a deadline for their return. The Agreement further states the commitment of the state authorities to conduct a substitute of assets that cannot be returned, in agreement with the Catholic Church. Finally, it is stated that compensation will be granted pursuant to the assessed value for those assets that will not be returned, or replaced with other substitute assets.

There are individual examples of the return of property to the Catholic Church in the City of Zagreb prior to 1990. One such example is the parish Church of the Immaculate Heart of Mary, whose lands were returned in 1990. Upon these lands, a parish church was built and the Faculty of Philosophy and Collegium of Society of Jesus renovated in 1995. However, the most significant return of property began following the conclusion of this Agreement with the Holy See. To date, 20 properties have been returned to the parishes, while 21 properties have been returned to the Zagreb Archdiocese. It should also be stated that the 27 structures making up the complex known as the 'Little Vatican' have remained under the ownership of the City of Zagreb, and in return the Zagreb Archdiocese received the King Tomislav military complex at Ilica 202.

\section{Figure 1: Properties returned to the Catholic Church following conclusion of the Agreement between the Republic of Croatia and the Holy See}

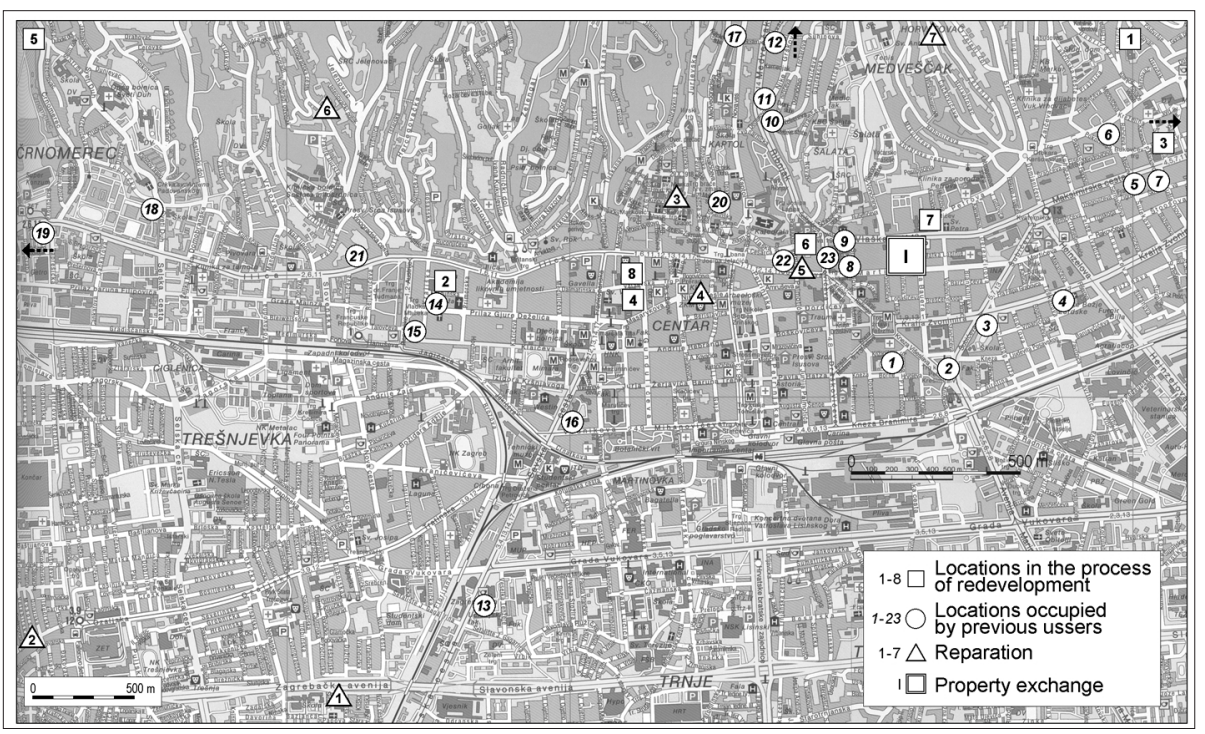




\section{State of returned properties and transformations executed}

When observing the manner of return of property in the City of Zagreb, pursuant to the agreements between the Republic of Croatia and the Holy See, it is possible to distinguish three different return methods. The first is the return of assets and the location. The second is reparation or a compensation of value. This method is carried out if it is not possible to return the property due to a significant change in its function. The third is a substitution of property. As previously stated, to date a total of 68 properties have been returned or substituted (reparations) to the Catholic Church in the City of Zagreb.

The process of transforming the returned buildings should be considered in the broader context of spatial and functional transformation of post-Socialist cities. With the return of valuable properties, particularly those in the city centre, there can be a change in the functional structure of those parts of the city. However, such changes of functional structure have not yet been recorded for Zagreb. The reason for this can be found in the relationship between the return of assets by law and in practice. Of the 41 properties returned to the parishes and the Zagreb Archdiocese, only 17 have been returned in practice. The remaining 24 properties have been returned by law, but they continue to be occupied by the previous inhabitants. An additional issue is the fact that the majority of those properties are buildings with a residential character, which significantly complicates the return procedure. From that aspect, the justification of the return of the property is questionable, and the question arises as to whether it would be suitable to consider the possibility of applying the German model of return, as described in the previous section.

Table 2 shows that virtually one-half of all returned properties have a mixed purpose. This is followed by empty buildings or buildings in which the transformation process is yet to begin. In the majority of mixed-purpose buildings, the previous users continue to occupy the space in most cases. This is seen in the example of the former Kinoteka complex on Kordunska Street. The complex was seized from the St. Blaise parish in 1946, and was used as a movie theatre and preschool. After its return, it is today used as a mixed-purpose building, including a private school, preschool (managed by the City of Zagreb), cafe, children's theatre, printing press and a hall used by the St. Blaise parish. 
Table 2: Properties returned in practice and their current purpose

\begin{tabular}{|c|c|c|c|c|}
\hline No. & Address & Previous purpose & New purpose & $\begin{array}{c}\text { Type of } \\
\text { transformation }\end{array}$ \\
\hline 1. & Kordunska 1, 3, 5 & $\begin{array}{l}\text { Movie theatre, } \\
\text { preschool }\end{array}$ & $\begin{array}{l}\text { Printing press for the } \\
\text { publication "Kršćanska } \\
\text { sadašnjost", Krijesnice } \\
\text { preschool, Zagreb } \\
\text { School of Management, } \\
\text { cafe bar Kinoteka, Hall } \\
\text { of the parish office of } \\
\text { St. Blaise [Sveti Blaž] }\end{array}$ & Mixed use \\
\hline 2. & Gundulićeva 10 & Faculty of Law & $\begin{array}{l}\text { Women's general } \\
\text { gymnasium } \\
\text { (preparatory school) }\end{array}$ & Educational \\
\hline 3. & Gundulićeva 12 & Faculty of Law & Empty & \\
\hline 4. & Varšavska 17 & $\begin{array}{l}\text { Administrative } \\
\text { School }\end{array}$ & Empty & \\
\hline 5. & Vlaška 38 & $\begin{array}{l}\text { Catholic Faculty of } \\
\text { Theology }\end{array}$ & $\begin{array}{l}\text { Catholic Faculty of } \\
\text { Theology }\end{array}$ & Educational \\
\hline 6. & Petračićev trg 4 & & & Governmental \\
\hline 7. & Jordanovac 110 & Undeveloped & $\begin{array}{l}\text { Church of the } \\
\text { Immaculate Heart } \\
\text { of Mary), Faculty } \\
\text { of Philosophy and } \\
\text { Collegium of the } \\
\text { Society of Jesus }\end{array}$ & $\begin{array}{l}\text { Mixed - } \\
\text { cultural } \\
\text { (religious), } \\
\text { educational }\end{array}$ \\
\hline 8. & Ribnjak 58 & Residential building & Building torn down & - \\
\hline 9. & Maksimirska 126 & $\begin{array}{l}\text { Undeveloped/sports } \\
\text { facilities }\end{array}$ & Undeveloped & Underway \\
\hline 10. & Črnomerec 94 & $\begin{array}{l}\text { Residential/ } \\
\text { craftsmen }\end{array}$ & $\begin{array}{l}\text { Protected cultural good, } \\
\text { residential, commercial } \\
\text { space }\end{array}$ & $\begin{array}{l}\text { Mixed } \\
\text { transformation }\end{array}$ \\
\hline 11. & Kaptol 27 & $\begin{array}{l}\text { Seat of the local } \\
\text { community board }\end{array}$ & $\begin{array}{l}\text { Restaurant, City of } \\
\text { Zagreb }\end{array}$ & $\begin{array}{l}\text { Mixed } \\
\text { (hospitality and } \\
\text { social) }\end{array}$ \\
\hline 12. & Vlaška 52 & No purpose & Shopping centre & Trade \\
\hline
\end{tabular}

Source: Mapping, November 2014 
Figure 2: Kinoteka complex on Kordunska Street 1-5

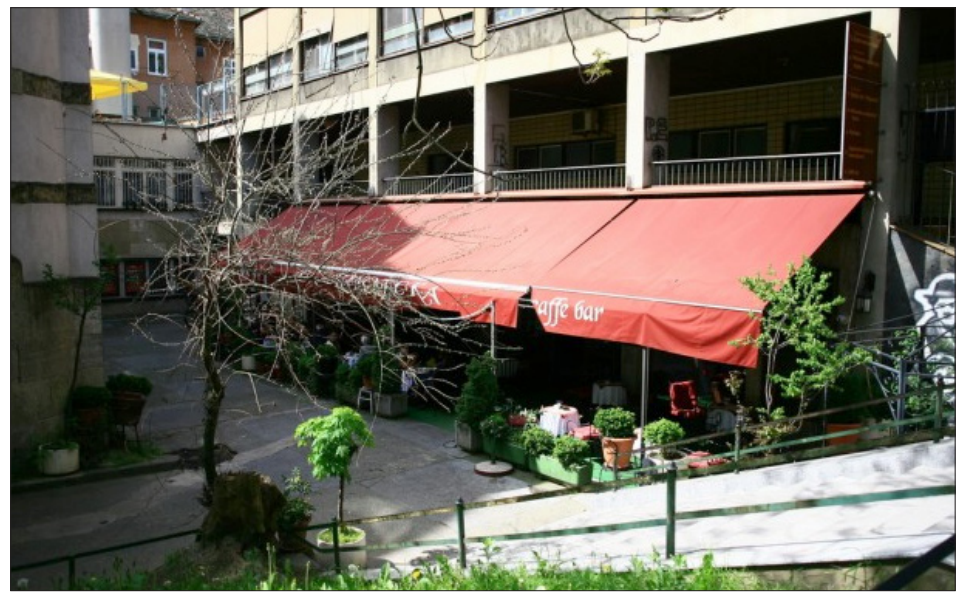

Source: photo by the author, November 2014

Of the total number of properties returned in practice, the transformation process has not yet begun in four. In two cases, these were formerly educational buildings. The Faculty of Law was housed at Gundulićeva St. 12, while the Administration School was at Varšavsa St. 17. Though the previous users vacated the premises due to the poor state of the building and danger of it caving in, reconstruction has not yet begun. An interesting example is at Maksimirska St. 126. This location is in the direct proximity of the Maksimir Stadium, and previously had a sporting purpose. After 1990, the property was returned to the Zagreb Diocese, and it was offered for sale to the City of Zagreb and the Croatian Football Federation. To date, an agreement on the transformation has not been reached.

\section{Figure 3: 'Little Vatican' complex}

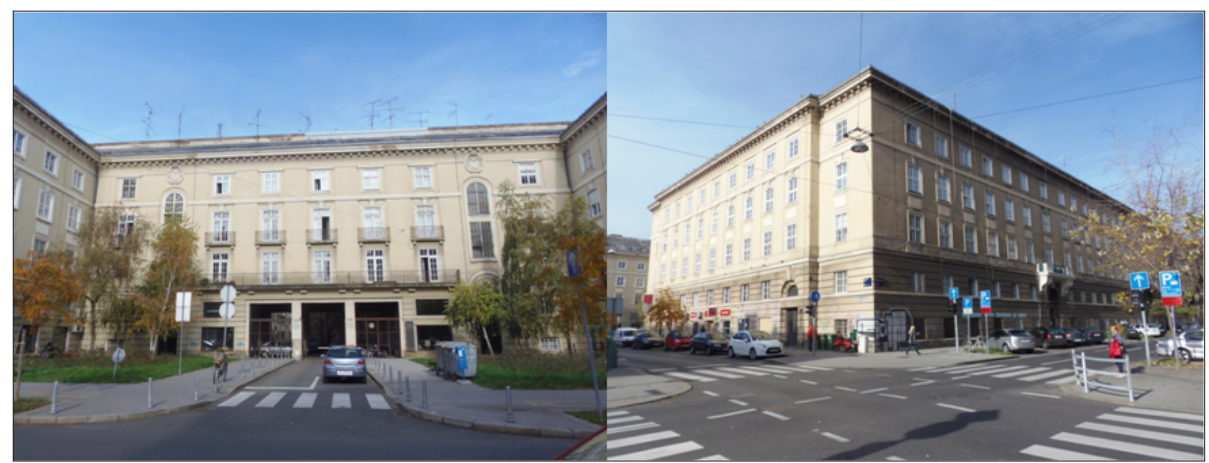

Source: photo by the author, November 2014 
Figure 4: King Tomislav military complex, today the Croatian Catholic University, Ilica 242

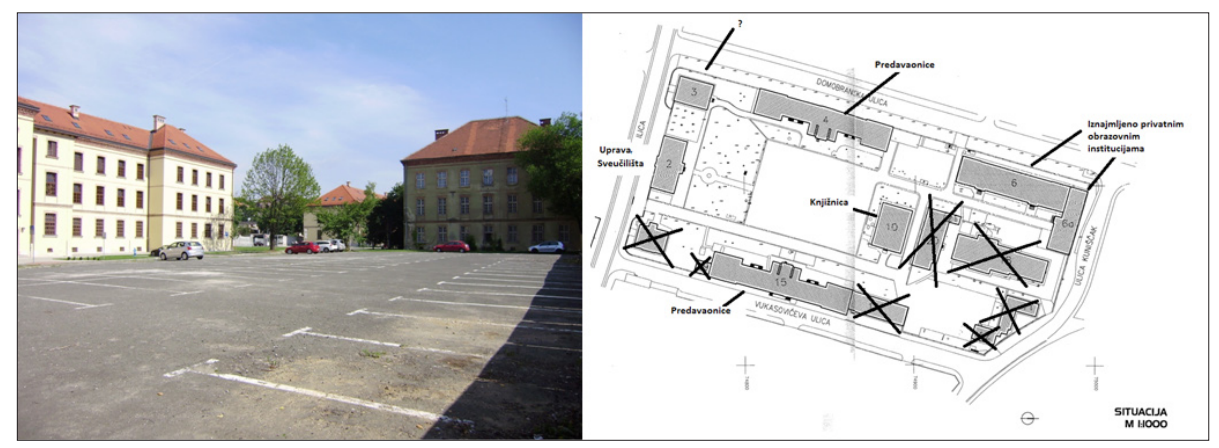

Source: photo by the author, August 2013, and Archive of the Croatian Catholic University

The third method of return is the substitution of property. There is one example of a successfully completed substitution of property in Zagreb. The complex closing off the streets Vlaška - Bauerova - Ratkayev Prolaz including 27 sites (15 buildings) in the very centre of the town that was confiscated in 1945 and given to the City of Zagreb was replaced by the location of the King Tomislav military complex at Ilica 242. The King Tomislav military complex was constructed in 1896 as the Home Defender's barracks, based on the designs of Milan Lenucci and Janko Holjac. Construction lasted from 1912 to 1918 and the complex was named after Count Miroslav Kulmer. In the period between the two world wars, the complex was renamed the King Alexander military complex. From 1945 to 1990, the complex was under the administration of the Yugoslav National Army. In 1990, the complex was renamed the King Tomislav military complex.

In 1999, the complex was handed over to the National Security Office, and in 2006 it was handed over for use to the Zagreb Archdiocese. The complex covers an area of 25,534 $\mathrm{m}^{2}$. To date, two of the structures have been refurbished and are used for educational purposes. The western building houses the Croatian Catholic University, while the northwestern building is leased by the university to a private higher education institute. Within the complex lands, plans are in place to construct a student campus and a business complex in the northern end of the property. The actualisation of these plans would mean functional and spatial changes to that part of the city.

\section{Conclusions}

After 1945, a strong movement to nationalise property swept though Yugoslavia and other Communist states. The Catholic Church was by far among the hardest hit by 
this nationalisation. Though individual cases of returns of property prior to 1990 exist, the actual return of property only began with the process of political and economic transition. The process of returning property in the countries of the former Communist system has been exceptionally slow. A particular issue is the lack of detailed information on the seized properties and their former owners.

After World War II, a total of 68 properties were seized from the Catholic Church in the City of Zagreb. To date, 20 sites have been returned to the parishes, and 21 to the Zagreb Archdiocese, while a complex of 27 locations has been returned for the site of the King Tomislav military complex.

Despite the fact that all the properties have been returned to the Catholic Church, only a small number of these structures have undergone transformation. The reason for this is that though the majority of these properties have been legally returned, most are still occupied by their former users, and these structures are primarily residential. Most of the structures that have been transformed have become mixed-use structures. Most often, a part of the former uses have been retained, and certain religious functions added. Such a type of transformation has not largely contributed to changing the spatial and functional structure of individual parts of the city. The exception is the planned and partially executed transformation of the King Tomislav military complex into the complex of the Croatian Catholic University.

In the forthcoming period, detailed analysis and comparative studies on the return of property in former Socialist states are required. It would also be desirable to conduct an in-depth analysis of neighbouring areas, to determine the needs of the local population, so as to ensure the implemented transformation also serves to increase the quality of life of the local population.

\section{References}

Acta Apostolicae Sedis (AAS), 29 [1937], pp. 65-106.

Acta Apostolicae Sedis (AAS), 89 (1997), pp. 277-302.

Acta Apostolicae Sedis (AAS), 91 (1999), pp. 170-178.

AKMADŽA M. (2003a), Politika državnih vlasti prema vjerskim školama u Zagrebačkoj nadbiskupiji 1945.-1966. In: Tkalčić, 7, pp. 157-196.

AKMADŽA M. (2003b), Oduzimanje imovine katoličke crkve i crkveno-državni odnosi od 1945. do 1966. Primjer Zagrebačke nadbiskupije, Tkalčić - Društvo za povjesnicu Zagrebačke nadbiskupije, Zagreb

AKmadžA M. (2004), Katolička crkva u Hrvatskoj i komunistički režim 1945.-1966. Rijeka, Otokar Keršovani.

AKmadžA M. (2008), Crkva i država. Dopisivanje i razgovori između predstavnika Katoličke crkve i komunističke državne vlasti u Jugoslaviji, svezak I., 1945.-1952. Zagreb, Društvo za povjesnicu Zagrebačke nadbiskupije Tkalčić. 
BatelJa J. (2010a), Blaženi Alojzije Stepinac - svjedok Evanđelja ljubavi. Životopis, dokumenti i svjedočanstva - prije, za vrijeme i nakon Drugoga svjetskog rata. Knjiga 1. Životopis, Postulatura blaženoga Alojzija Stepinca, Zagreb, pp. 373-375.

BAtelJA J. (2010b), Blaženi Alojzije Stepinac - svjedok Evanđelja ljubavi. Životopis, dokumenti i svjedočanstva - prije, za vrijeme i nakon Drugoga svjetskog rata. Knjiga 3. Dokument, Postulatura blaženoga Alojzija Stepinca, Zagreb, pp. 281-285.

Born K.M. (1997), The return of confiscated land and property in the new Länder: The process and its geographical implications, In: Applied Geography, 17, 4, pp. 371-384.

ČAldarović O., ŠArinić J. (2008), First signs of gentrification? Urban regeneration int he transitional society: the case of Croatia. In: Sociologija i prostor, 46, 3-4, pp. 369-381.

CizLer J. (2012), Urban regeneration effects on industrial heritage and local community. Case study Leeds, UK. In: Sociologija i prostor, 50, 2. pp. 223-236.

DAmIš I. (1995), Ulomci za povijest Crkve u Hrvata. Zagreb, Hrvatsko književno društvo sv. Jeronima.

HR - Zagrebačka nadbiskupija - Nadbiskupki duhovni stol (ZGNB - NDS); Kartoteka: Povrat crkvene imovine.

HR - ZGNB - NDS; Kartoteka: Povrat crkvene imovine.

JAKOVČIĆ M. (2014), Od industrijsko-vojne četvrti do novih gradskih funkcija - urbanogeografska analiza funkcionalne prenamjene industrijske i vojne baštine na području gradske četvrti Črnomerec u Zagrebu. In: Palinić N., Rotim Malvić J., Đekić V. (eds.), Zbornik V. međunarodne konferencije o industrijskoj baštini posvećen temi Rijeka i industrijsko graditeljsko naslijeđe baština arhitekture i građevinarstva PRO TORPEDO Rijeka, pp. 813-830. Rijeka, PRO TORPEDO.

Kiss É., (2009), Major trends in the development of industrial areas of Budapest in the early $21^{\text {st }}$ century. In: Hungarian Geographical Bulletin, 58, 3, pp. 163-180.

KNEŽEviĆ S. (1999), Povijest područja bivše Rudolfove vojarne u Trga Francuske republike u Zagrebu. In: Godišnjak zaštite spomenika kulture Hrvatske, 22/23, pp. 57-72.

KNEŽEviĆ S. (2003), Rudolfova vojarna i Trg Francuske Republike - novi zapadni perivoj. In: KNEŽEvić S. (ed.), Zagreb u središtu, pp. 101-127. Zagreb, Barbat.

KNEŽEvić S. (2011), K. u. K. vojarne u Zagrebu. In: KNEŽEvić S. (ed.), Zagreb: grad, memorija, art, pp. 61-99. Zagreb, Meandarmedia.

KNeŽEviĆ S. (2011), Opstanak transformacijom. Povijest Petrinjske vojarne i projekt obnove Zvonimira Krznarića. In: KNeŽEviĆ S. (ed.), Zagreb: grad, memorija, art, pp. 195-207. Zagreb, Meandarmedia.

Korbonski A. (2000), Poland ten years after: the church. In: Communist and Post-Communist Studies, 33, pp. 123-146.

Kотus J. (2006), Changes in the Spatial Structure of a Large Polish City - the Case of Poznan. In: Cities, 23, 5, pp. 364-381.

Kozminski A.K. (1997), Restitution of Private Property, Re-privatization in Central and Eastern Europe. In: Communist and Post-Communist Studies, 30, 1, pp. 95-106.

Kožul S. (1998), Martirologij Crkve zagrebačke. Zagreb, Tkalčić - Društvo za povjesnicu Zagrebačke nadbiskupije.

Lenin Collected Works, Progress Publishers, 1965, Moscow, Vol. 10, pp. 83-87<http://www. marxists.org/archive/lenin/works/1905/dec/03.htm > 
Maticka M. (2007), Agrarna reforma i kolonizacija (1945.-1948.) i njihov odraz na nacionalni sastav pučanstva u koloniziranim krajevima Hrvatske. In: PERIĆ I., Povijest Hrvata, svezak III. Od 1918. do danas, Školska knjiga, p. 305. Zagreb, Školska knjiga.

Perić I. (2007), Konfiskacije, sudski procesi i nacionalizacija. In: Perić I., Povijest Hrvata, svezak III. Od 1918. do danas, p. 298. Zagreb, Školska knjiga.

PolansKa D. (2008), Decline and revitalization in postcommunist urban context: A case study of the Polish city - Gdansk. In: Communist and Post-Communist Studies, 41, 3, pp. 359374.

RADELIĆ Z. (2006), Hrvatska u Jugoslaviji 1945-1991.: od zajedništva do razlaza. Zagreb, Školska knjiga.

ReImAnN B. (1997), The transition from people's property to private property: Consequences of the restitution principle for urban development and urban renewal in East Berlin's innercity residential areas. In: Applied Geography, 17, 4, pp. 301-313.

SvirČić Gotovac A. (2011), Aspekt ugroženosti javnih prostora. In: ČAPo J., Gulin ZRnić V. (eds.), Mjesto nemjesto, pp. 303-316. Zagreb, Biblioteka Nova etnografija.

Sykora L. (1999), Processes of socio-spatial differentiation in post-communist Prague. In: Housing Studies, 14, 5, pp. 679-701.

Ugovori između Svete Stolice i Republike Hrvatske. Hrvatska biskupska konferencija, Zagreb, 2001., pp. 27-37, 41-50, 53-58.

Ugovori između Svete Stolice i Republike Hrvatske. Hrvatska biskupska konferencija, Zagreb, 2001., pp. 61-69. 